\title{
Frequency of Beta-Hemolytic Streptococci Group A, C and G in The Tonsillopharyngeal Flora of Individuals of Families with a Case of Rheumatic Fever and/or Rheumatic Heart Disease
}

\author{
SALAH A. SHOHEIB, M.D. ${ }^{\mathbf{1}}$; AHMED O.A. SHALMA, M.Sc. ${ }^{2}$; AMAL S. EL-BENDARY, M.D. ${ }^{\mathbf{3}}$;

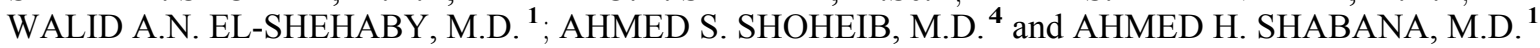 \\ The Department of Pediatric, Faculty of Medicine, Tanta University ${ }^{2}$, Al-Mabara Hospital, Ministry of Health ${ }^{2}$, \\ The Departments of Clinical Pathology ${ }^{3}$ and Cardiology ${ }^{4}$, Faculty of Medicine, Tanta University
}

\begin{abstract}
Background: Rheumatic fever is an inflammatory reaction that can develop as a complication of a Group A streptococcal infection. The role of Group C (GCS) and Group G (GGS) in disease burden is under recognized the present study is carried out to find the prevalence of GAS, GCS and GCS in throat of rheumatic families.

Aim of Study: Isto explore the frequency of beta-hemolytic streptococci Group A, C and G in the tonsillopharyngeal flora of individuals of families with a case of rheumatic fever and/ or rheumatic heart disease.
\end{abstract}

Patients and Methods: This study was carried out on 20 families of children with rheumatic fever and/or rheumatic heart disease chosen from children attending to Pediatric Clinic at Tanta University Hospital and El-Menshawe General Hospital in Gharbia governorate ten families have animals (cattle and/or birds) and ten families have not. Ten healthy families enrolled as controls five families have animals (cattle and/or birds) and five families have not.

Results: In our study (20\%) of children in rheumatic families (cases and siblings) less than 18 years and $(15.63 \%)$ of children of controls in the same age group were GAS positive and GCS was present in $(1.67 \%)$ and it is absent in children of controls. As regarding GGS (5\%) of children in rheumatic families and $(3.13 \%)$ of children of controls in the same age group were GGS positive.

Conclusion: Our study concluded that Group A beta hemolytic streptococci is the most prevalent type of beta hemolytic streptococci compared to Group C and G streptococci in throat of children with ARF/RHD as well as their siblings.

Key Words: GAS Group A streptococcal - GCS/GCS Group $C$ and $G$ streptococci - RF rheumatic fever$R H D$ rheumatic heart disease.

Correspondence to: Dr. Salah A. Shoheib, The Department Pediatric, Faculty of Medicine, Tanta University

\section{Introduction}

RHEUMATIC fever is a multisystem, immunemediated, inflammatory disease that occurs predominantly in childhood and adolescence and follows infection with the bacterium Streptococcus pyogenes [1]. ARF is characterised by non suppurative inflammatory lesions in the heart, subcutaneous tissue and central nervous system [2]. Of the associated symptoms, only damage to valve tissue within the heart or Rheumatic Heart Disease (RHD) can become chronic condition leading to congestive heart failure, strokes, endocarditis and death [3] There is strong evidence for the causative relationship with S. pyogenes, including epidemiological data linking outbreaks of ARF following outbreaks of S. pyogenes pharyngeal infection [1] . Controlled clinical trials demonstrating that treatment of S. pyogenes pharyngitis reduces the risk of ARF by approximately $80 \%$ [4]. If supported by evidence of preceding Group A streptococcal infection, the presence of two major manifestation or one major and two minor indicates high probability of ARF. Failure to fulfill the Jones criteria makes the diagnosis unlikely but not impossible. Clinical judgment is required. The World Health Organization (WHO) follows the Jones criteria for the diagnosis of ARF, but possible recurrences require only two minor criteria plus evidence of recent streptococcal infection [5]. Jones criteria include major criteria are as follows polyarthritis of predominantly large joints, carditis, skin and soft tissue changes (erythema marginatum and subcutaneous nodules) and Sydenham's chorea. Minor criteria are as follows: Arthralgia, fever elevated ESR or CRP level and prolonged PR interval [6]. As regards diagnosis there is no single specific laboratory test to confirm 
the diagnosis of ARF. Throat culture remains the criterion standard for confirmation of Group A streptococci the goals of treatment of rheumatic fever are to destroy Group A streptococcal bacteria, relieve symptoms, control inflammation and prevent recurring episodes of rheumatic fever. Treatment used for rheumatic fever include: Antibiotics, anti-inflammatory drugs. Surgical intervention required only to treat long term valvular cardiac complications of ARF [7].

Aim of the Work: Is to explore the frequency of beta-hemolytic streptococci Group A, C and G in the tonsillopharyngeal flora of individuals of families with a case of rheumatic fever and/or rheumatic heart disease.

\section{Patients and Methods}

This study was carried out on 20 families of children with rheumatic fever and/or rheumatic heart disease chosen from children attending to Pediatric Clinic at Tanta University Hospital and El-Menshawe General Hospital in Gharbia governorate during 2017 ten families have animals (cattle and/or birds) and ten families have not. Ten healthy families enrolled as controls five families have animals (cattle and/or birds) and five families have not.

Inclusion criteria: Families having history of rheumatic fever and or rheumatic heart disease in one member.

Exclusion criteria: Children received antibiotics within the previous two weeks before enrollment and immunocompromised children.

\section{Investigations included:}

A- Routine investigations: All laboratory investigations were done as routine work up for all children and their families. ESR, ASOT, Creactive protein, Blood group test.

$B$ - Research work investigations: Throat culture samples were collected from posterior oropharyngeal wall and the tonsillary area bilaterally with a sterile cotton swab. Avoid touching the tongue cheeks and teeth with swab. This technique was standardized by the use of an illustration of the anatomical area. The specimen were transported to the microbiology laboratory and examined without delay. Samples were inoculated on to 5\% sheep blood agar. Plates were incubated in $37^{\circ} \mathrm{C}$ in aerobic atmosphere for 48 hours. Growth of the bacteriae were checked twice after 24 and 48 hours. The sam- ples which had beta hemolytic streptococci were tested with 0.04 units of Bacitracin disc for susceptibility. All beta hemolytic streptococci were grouped according to Lancefield latex agglutination test ImmuLexTM Streptococcus Group Kit. Statens Serum Institut CO S, Artillerivej, 2300, copenhagen S, Denmar. A positive result in one of latex reagents identifies the group example if the there only a positive reaction in the Group A latex reagent, the strain is a streptococcus Group A.

\section{Results}

Table (1) shows that there is no significant difference between studied groups except the siblings of patients as compared with siblings of controls with $(p$-value $=0.001 *)$ as the mean value of siblings of patients 12.87 while that of controls is 7.318 .

Table (2) shows that $16(61.54 \%)$ of patients cases were blood Group A while 2 (20\%) of control cases were blood Group A with significant increase in patients cases group ( $p$-value $=0.001 *$ ). Comparing different blood groups of patients cases shows also significant increase in blood Group A ( $p$-value $\left.<0.001^{*}\right)$. There is no significant difference between patients and controls groups as regard blood groups $\mathrm{B}+, \mathrm{O}+$ and $\mathrm{AB}+$.

Table (4) shows that $121 \% 3(5 \%)$ of patients (cases and sibling less than 18) were GGS positive, while $1(3.13 \%)$ of control (case and sibling less than 18$)$ were GGS positive. 1 (1.67\%) of patients (cases and of control (cases and sibling less than 18) were GCS positive.

Table (1): Age distribution among the studied groups.

\begin{tabular}{|c|c|c|c|c|}
\hline \multirow{2}{*}{ Age } & \multicolumn{2}{|c|}{ Groups } & \multicolumn{2}{|c|}{$t$-test } \\
\hline & $\begin{array}{c}\text { Patients } \\
\text { Mean } \pm \text { SD }\end{array}$ & $\begin{array}{c}\text { Controls } \\
\text { Mean } \pm \text { SD }\end{array}$ & $t$ & $p$-value \\
\hline \multicolumn{5}{|l|}{ Case: } \\
\hline Range & $5-15$ & $6-15$ & -1.068 & 0.293 \\
\hline Mean \pm SD & $9.346 \pm 2.979$ & $10.500 \pm 2.677$ & & \\
\hline \multicolumn{5}{|l|}{ Father: } \\
\hline Range & $29-54$ & $32-45$ & 0.631 & 0.534 \\
\hline Mean \pm SD & $40.889 \pm 7.707$ & $39.200 \pm 4.566$ & & \\
\hline \multicolumn{5}{|l|}{ Mother: } \\
\hline Range & $24-50$ & $30-43$ & -0.449 & 0.657 \\
\hline Mean \pm SD & $35.200 \pm 6.437$ & $36.200 \pm 3.910$ & & \\
\hline \multicolumn{5}{|l|}{ Sibling: } \\
\hline Range & $2-30$ & $3-13$ & 3.409 & $0.001 *$ \\
\hline Mean \pm SD & $12.870 \pm 7.408$ & $7.318 \pm 2.533$ & & \\
\hline
\end{tabular}


Table (2): Comparison between different blood groups of cases in rheumatic families and control families.

\begin{tabular}{|c|c|c|c|c|c|c|c|c|}
\hline \multirow{3}{*}{$\begin{array}{l}\begin{array}{r}\text { Blood } \\
\text { group }\end{array} \\
\text { Family's }\end{array}$} & \multicolumn{6}{|c|}{ Groups } & \multicolumn{2}{|c|}{ Chi-square } \\
\hline & \multicolumn{2}{|c|}{ Patients } & \multicolumn{2}{|c|}{ Controls } & \multicolumn{2}{|c|}{ Total } & \multirow{2}{*}{$x^{2}$} & \multirow{2}{*}{$\begin{array}{c}p- \\
\text { value }\end{array}$} \\
\hline & $\mathrm{N}$ & $\%$ & $\mathrm{~N}$ & $\%$ & $\mathrm{~N}$ & $\%$ & & \\
\hline \multicolumn{9}{|l|}{ Case: } \\
\hline $\mathrm{A}+$ & 16 & 61.54 & 2 & 20.00 & 18 & 50.00 & 10.889 & $0.001 *$ \\
\hline $\mathrm{B}+$ & 4 & 15.38 & 3 & 30.00 & 7 & 19.44 & 0.143 & 0.705 \\
\hline $\mathrm{O}+$ & 2 & 7.69 & 1 & 10.00 & 3 & 8.33 & 0.333 & 0.564 \\
\hline $\mathrm{AB}+$ & 4 & 15.38 & 4 & 40.00 & 8 & 22.22 & 0.000 & 1.000 \\
\hline \multicolumn{9}{|l|}{ Chi-Square: } \\
\hline$x^{2}$ & \multicolumn{2}{|c|}{18.923} & \multicolumn{2}{|c|}{2.000} & \multicolumn{2}{|c|}{13.556} & & \\
\hline$p$-value & \multicolumn{2}{|c|}{$<0.001^{*}$} & \multicolumn{2}{|c|}{0.572} & \multicolumn{2}{|c|}{$0.004 * *$} & & \\
\hline
\end{tabular}

Table (3): Comparison of GAS, GCS and GGS positive between studied groups.

\begin{tabular}{|c|c|c|c|c|c|c|c|c|}
\hline \multirow[b]{3}{*}{ Family's } & \multicolumn{6}{|c|}{ Groups } & \multicolumn{2}{|c|}{ Chi-square } \\
\hline & \multicolumn{2}{|c|}{ Patients } & \multicolumn{2}{|c|}{ Controls } & \multicolumn{2}{|c|}{ Total } & \multirow{2}{*}{$x^{2}$} & \multirow{2}{*}{$\begin{array}{c}p- \\
\text { value }\end{array}$} \\
\hline & $\mathrm{N}$ & $\%$ & $\mathrm{~N}$ & $\%$ & $\mathrm{~N}$ & $\%$ & & \\
\hline \multicolumn{9}{|l|}{ Case: } \\
\hline Negative & 19 & 73.08 & 8 & 80.00 & 27 & 75.00 & 0.462 & 0.794 \\
\hline GAS & 6 & 23.08 & 2 & 20.00 & 8 & 22.22 & & \\
\hline GGS & 1 & 3.85 & 0 & 0.00 & 1 & 2.78 & & \\
\hline GCS & 0 & 0.00 & 0 & 0.00 & 0 & 0.00 & & \\
\hline \multicolumn{9}{|l|}{ Father: } \\
\hline Negative & 16 & 88.89 & 10 & 100.00 & 26 & 92.86 & 1.197 & 0.274 \\
\hline GAS & 2 & 11.11 & 0 & 0.00 & 2 & 7.14 & & \\
\hline GGS & 0 & 0.00 & 0 & 0.00 & 0 & 0.00 & & \\
\hline GCS & 0 & 0.00 & 0 & 0.00 & 0 & 0.00 & & \\
\hline \multicolumn{9}{|l|}{ Mother: } \\
\hline Negative & 19 & 95.00 & 9 & 90.00 & 28 & 93.33 & 0.268 & 0.605 \\
\hline GAS & 1 & 5.00 & 1 & 10.00 & 2 & 6.67 & & \\
\hline GGS & 0 & 0.00 & 0 & 0.00 & 0 & 0.00 & & \\
\hline GCS & 0 & 0.00 & 0 & 0.00 & 0 & 0.00 & & \\
\hline \multicolumn{9}{|l|}{ Sibling: } \\
\hline Negative & 37 & 80.43 & 18 & 81.82 & 55 & 80.88 & 0.487 & 0.922 \\
\hline GAS & 6 & 13.04 & 3 & 13.64 & 9 & 13.24 & & \\
\hline GGS & 2 & 4.35 & 1 & 4.55 & 3 & 4.41 & & \\
\hline GCS & 1 & 2.17 & 0 & 0.00 & 1 & 1.47 & & \\
\hline
\end{tabular}

Table (4): GAS, GCS and GGS in cases and their siblings who are less than 18 years in rheumatic families and controls.

\begin{tabular}{|c|c|c|c|c|c|c|c|c|}
\hline \multirow{3}{*}{$\begin{array}{l}\text { Case and } \\
\text { sibling } \\
<18 \text { years }\end{array}$} & \multicolumn{6}{|c|}{ Groups } & \multicolumn{2}{|c|}{ Chi-square } \\
\hline & \multicolumn{2}{|c|}{ Patients } & \multicolumn{2}{|c|}{ Controls } & \multicolumn{2}{|c|}{ Total } & \multirow{2}{*}{$x^{2}$} & \multirow{2}{*}{$\begin{array}{c}p- \\
\text { value }\end{array}$} \\
\hline & $\mathrm{N}$ & $\%$ & $\mathrm{~N}$ & $\%$ & $\mathrm{~N}$ & $\%$ & & \\
\hline \multicolumn{9}{|l|}{ GAS: } \\
\hline Negative & 48 & 80.00 & 27 & 84.38 & 75 & 81.52 & 0.265 & 0.607 \\
\hline Positive & 12 & 20.00 & 5 & 15.63 & 17 & 18.48 & & \\
\hline \multicolumn{9}{|l|}{$G G S:$} \\
\hline Negative & 57 & 95.00 & 31 & 96.88 & 88 & 95.65 & 0.176 & 0.674 \\
\hline Positive & 3 & 5.00 & 1 & 3.13 & 4 & 4.35 & & \\
\hline \multicolumn{9}{|l|}{ GCS: } \\
\hline Negative & 59 & 98.33 & 32 & 100.00 & 91 & 98.91 & 0.539 & 0.463 \\
\hline Positive & 1 & 1.67 & 0 & 0.00 & 1 & 1.09 & & \\
\hline
\end{tabular}

\section{Discussion}

In the present study, the age of patients ranged from 5-15 years old with mean value of 9.3 years. Most studies attribute this age of incidence to be repeated sore throat and streptococcal infection in school children [8,9]. Previous reports have indicated an association between $\mathrm{ABO}$ blood group and RF, but the results differ from one study to another. In the present work, when comparing the results of $\mathrm{ABO}$ blood group of rheumatic patients to that of control, a definite increase in $\mathrm{A}+(61.54 \%)$ at expense of $\mathrm{AB}+, \mathrm{B}+$ and $\mathrm{O}+$. Shoheib et al. [10] concluded that both $\mathrm{A}+$ and $\mathrm{B}+$ blood groups were more common in patients than in controls. In our study $(20 \%)$ of children in rheumatic families (cases and siblings) less than 18 years and (15.63\%) of children of controls in the same age group were GAS positive with no significant difference, this similar results in cases and controls is attributed to all cases already on long acting penicillin. Similar results were that of Zaoutis et al. [11] in Pennsylvania who reported that the percentage of GAS in throat of patient had pharengitis was $(21.8 \%)$ of 2085 patient, while in asymptomatic control group it was (14.9\%) of 194 case Martin and Barbadora, 12 their results of throat cultures were available for 231 persons; $36 \%$ of children with ARF and $14 \%$ of family members were positive for GAS while in our study $23.08 \%$ of cases were positive for GAS and $8.18 \%$ of family members (siblings and parents) also were positive. According to Naik et al. [13] in Karnataka the incidence of GAS among pharyngitis cases was $(9.17 \%)$ of 218 patients while it was $(7.31 \%)$ in controls. Different studies have quoted rates of the prevalence of GAS from throat culture of patients had pharengitis ranging from $2.8 \%$ to $40 \%$ [14-17]. While Asymptomatic Carriage rate of GAS in different reports ranging from $1.3 \%$ to $14.9 \%,[\mathbf{1 4 , 1 7 , 1 8}]$. Our study revealed that GCS was present in $(1.67 \%)$ of children in rheumatic families (cases and siblings) less than 18 years and it is absent in children of controls in the same age group were GCS positive with no significant difference. Similar results were that of Zaoutis et al. [14] who recorded a low prevalence of GCS in cases with pharengitis and controls, the percentages were respectively (1.6\%) and $(0.5 \%)$, while in Spain, Group C streptococcus prevalence was $5.2 \%$ among children who had symptoms of tonsillopharyngitis [19]. As regarding GGS, in our study (5\%) of children in rheumatic families (cases and siblings) less than 18 years and $(3.13 \%)$ of children of controls in the same age group were GGS positive with no significant difference. Also Zaoutis et al. [11] reported that GGS in cases with pharengitis was $(1.5 \%)$ while it was $(1.0 \%)$ in 
asymptomatic controls. McDonald et al. [20] reported that throat carriage was $0.7 \%$ for GCS, $5.1 \%$ for GGS. In summary the frequency of GCS and GGS isolates from acute pharyngitis from different regions ranges from $0.7 \%$ to $6.24 \%$ and $3.74 \%$ to $5.1 \%$, respectively $[\mathbf{1 9 , 2 1}]$. While Carriage rate of GCS and GGS from asymptomatic individuals ranging from $(0.97 \%$ to $11 \%)$, and $(2.4 \%$ to $11 \%)$ respectively $[\mathbf{1 4}, \mathbf{1 8}]$. The limitations in our study include inability to confirm presence of GGS and GCS in throat culture by serological tests which detect antibodies against these bacteria, another limitation is inability to differentiate between the animal and the human source of GGS and GCS positive cultures. These tests are difficult and done only in few laboratories in the world [22].

\section{Conclusion:}

Our study concluded that Group A beta hemolytic streptococci is the most prevalent type of beta hemolytic streptococci compared to Group $\mathrm{C}$ and $\mathrm{G}$ streptococci in throat of children with ARF/RHD as well as their siblings. And it is also the most prevalent type in throat of children of control families.

Acknowledgments: This research was carried out without funding.

Conflicts of interest: No conflicts of interest declared.

Authors' contributions: All authors had equal role in design, work, statistical analysis and manuscript writing. All authors have approved the final article work.

\section{References}

1- STEER: Historical aspects of rheumatic fever, Journal of Paediatrics and Child Health, 51 (1): 21-27, 2015.

2- SHULMAN: Nelson 20th edition rheumatic fever, Chapter 183, p. 1334, 2016.

3- GUPTA, CHATTERJEE, AGARWAL, et al.: Rheumatic fever: A reappraisal, Journal Indian Academy of Clinical Medicine, 11: 2 1, 2010.

4- ROBERTSON, VOLMINK and MAYOSI: Antibiotics for the primary prevention of acute rheumatic fever: A metaanalysis. BMC Cardiovasc. Disord, 31: 11, 2005.

5- CARAPRTIS, STEER and MULLHOOLLAND: The global burden of group A streptococcal disease. Lancet Infect. Dis., 5: 685-94, 2005.

6- LOZANO, NAGHAVI, FOREMAN, et al.: Global and regional mortality from 235 causes of death for 20 age groups in 1990 and 2010: A systematic analysis for the Global Burden of Disease Study 2010. Lancet, 380: 2095128,2012
7- CILLIERS, ADLER and SALOOJEE: Anti-inflammatory treatment for carditis in acute rheumatic fever Cochranedatabaseofsystematicreviews, Iss 5, Art. No.: CD003176, 2015.

8- NAVANEETH, NIMANANDA and CHAWDA: Prevalence of streptococci carrier rate among school children in salm. Indian J. Pediatr., 68: 988-986, 2001.

9- LAWRENCE, CARAPETIS, GRIFFITHS, et al.: Acute rheumatic fever and rheumatic heart disease incidence and progression in the Northern Territory of Australia 1997 to 2010, Circulation, 128: 492, 2013.

10- SHOHEIB, ABDEL-FATTAH and ZOAHIR: ABO blood group as a marker of RF/RHD susceptibility among siblings of families with a case of RHD the Journal of Pediatric Club, 9: 78, 2009.

11-ZAOUTIS, ATTIA, GROSS, et al.: The role of group C and group $\mathrm{G}$ streptococci in acute pharyngitis in children,Clinical Microbiology and Infection, 10 (1): 37-40, 2004.

12- MARTIN and BARBADORA: Continued high case load of rheumatic fever in Western Pennsylvania: Possible rheumatogenicemm types of Streptococcus pyogenes, J. Pediatr., 149 (1): 58-63, 2006.

13-NAIK B., NADAGIR S.D. and BIRADAR A.: Prevalence of beta-hemolytic streptococci Groups A, C, and G in patientswith acute pharyngitis, Journal of Laboratory Physicians, 16; 57 (12): 452-4, 2016.

14- BRAMHACHARI, KAUL, McMILLAN, et al.: Disease burden due to Streptococcus dysgalactiae subsp. Equisimilis (Group $\mathrm{G}$ and $\mathrm{C}$ streptococcus) is higher than that due to Streptococcus pyogenes among Mumbai school children. Journal of Medical Microbiology, 59 (2): 2203, 2010 .

15- KONEMAN, ALLEN, JANDA, et al.: Koneman's Color Atlas and Textbook of Diagnostic Microbiology. Gram Positive Cocci Part II: Streptococci, Enterococci and the "Streptococcus -Like" Bacteria. 6 th ed. Philadelphia: Lippincott Williams and Wilkins Publishers, p. 672-764, 2006.

16- GLEESON, BROWNING, BURTON, et al.: Scott Brown's Otorhinolaryngology, Head and Neck Surgery. The Upper Digestive Tract. Acute and Chronic Pharyngeal Infection. 7th ed., Vol. 2. Great Britain: Edward Arnold Publishers, p. 1981-2024, 2008.

17- LONGO, KASPER, JAMESON, et al.: Harrison's Principles of Internal Medicine. Pharyngitis, Sinusitis, Otitis and Other Upper Respiratory Tract Infections. 18 th ed. Vol. 1. United States of America: McGraw-Hill Publishers, p. 255-67, 2012.

18- LLOYD, JACOB and MENON: Pharyngeal carriage of group A streptococci in school children in Chennai. Indian J. Med. Res., 124: 195-8, 2006.

19- CITORES, MENDEZ, PARDILLO, et al.: Incidence of streptococcal pharyngitis. An Pediatr., 67 (3): 220-4, 2007.

20- McDONALD, TOWERS, ANDREWS, et al.: Epiemiology of streptococcus dysgalactiae subsp. Equisimilis in tropical communities, Northern Australia. Emerging Infectious Diseases, 13: 1694-700, 2007. 
21- MENON, LLOYD and JACOB: Should Bacitracin sensitivity be used in the presumptive identification of group A Streptococci? Indian Journal of Medical Microbiology, 23 (4): 275, 2005.
22- KBOS and MACH: Pathogenicity of virulent species of group c streptococci in human, Canadian journal of infectious diseases and medical microbiology, Volume 2017 Article ID 9509604, 5 pages, 2017.

\section{تحديد نسبة إصابة الحلق واللوزتين بالبكتريا العقدية ألواتية

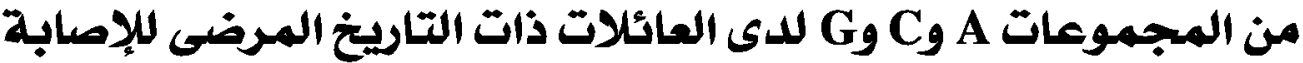

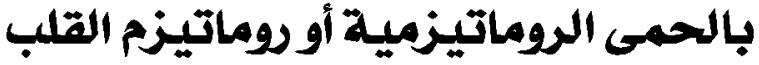

تعتبر العمى الروماتيزمية احدى المضاعفات غير القيحية لإلتهاب البلعىم الذى تسبيه البكتريا العقدية من المجموعة A . لكن فى الآرنه

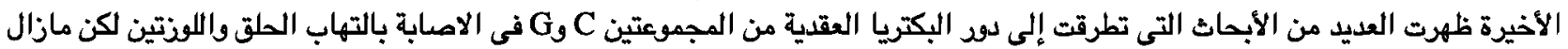

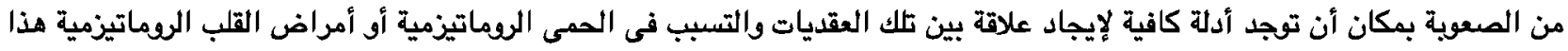

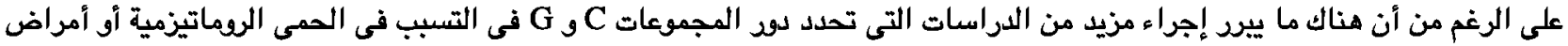
القلب الوماتيزمية.

الهدف من البحث: هوتصديد نسبة إصابة الحلق واللوزتين بالبكتريا العقدية من المجموعات A و C لدى العائلات ذات التاريخ المرضى للإصابة بالممى الروماتيزمية أو روماتيزم القدئ.

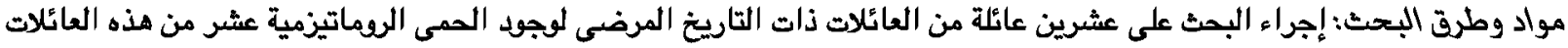

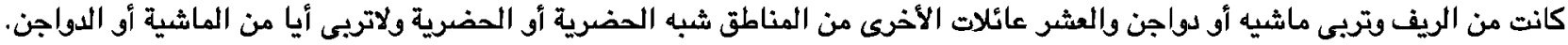

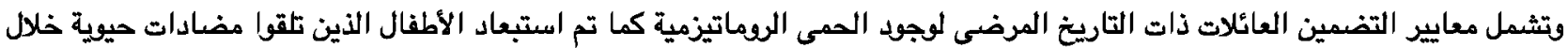

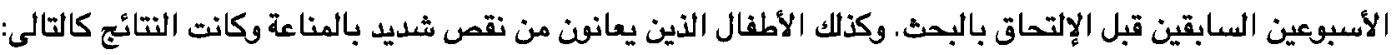
- متوسط أعمار المرضى المصابين بالحمى الرماتيزمية أو أمراض القلب الرماتيزمية بين م إلى 10 - هناك علاقة بين فصائل الدم والإصابة بالحمى الروماتيزمية أو أمراض القلب الروماتيزمية اذ وجد ان عه. الح٪ من الصالات يحملون فصيلة الدم A ( الموجية.

- يوضح البحث ان نسبة انتشار البكتريا العقدية من المجموعة A هى الأبر مقارنة بالمجموعات Cو Cي الاطفال المصابين بالحمى الروماتيزمية

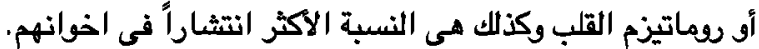

